\title{
Correction to: lonizing radiation modulates the phenotype and function of human CD4+ induced regulatory $T$ cells
}

Samantha S. Beauford, Anita Kumari and Charlie Garnett-Benson ${ }^{*}$

\section{Correction to: BMC Immunol 21, 18 (2020) \\ https://doi.org/10.1186/s12865-020-00349-w}

It was highlighted that in the original article [1] some of the bar graphs of Fig. 4 were blank. This Correction article shows the correct Fig. 4. The original article has been updated. The Publisher would like to apologize to the authors and readers for the inconvenience.

Published online: 15 June 2020

\section{Reference}

1. Beauford, et al. Ionizing radiation modulates the phenotype and function of human CD4+ induced regulatory T cells. BMC Immunol. 2020;21:18 https:// doi.org/10.1186/s12865-020-00349-w.

The original article can be found online at https://doi.org/10.1186/s12865020-00349-w.

* Correspondence: cgarnettbenson@gsu.edu

Department of Biology, Georgia State University, 161 Jesse Hill Jr. Dr, Atlanta, GA 30303, USA

(c) The Author(s). 2020 Open Access This article is licensed under a Creative Commons Attribution 4.0 International License, which permits use, sharing, adaptation, distribution and reproduction in any medium or format, as long as you give appropriate credit to the original author(s) and the source, provide a link to the Creative Commons licence, and indicate if changes were made. The images or other third party material in this article are included in the article's Creative Commons licence, unless indicated otherwise in a credit line to the material. If material is not included in the article's Creative Commons licence and your intended use is not permitted by statutory regulation or exceeds the permitted use, you will need to obtain permission directly from the copyright holder. To view a copy of this licence, visit http://creativecommons.org/licenses/by/4.0/ The Creative Commons Public Domain Dedication waiver (http://creativecommons.org/publicdomain/zero/1.0/) applies to the data made available in this article, unless otherwise stated in a credit line to the data. 


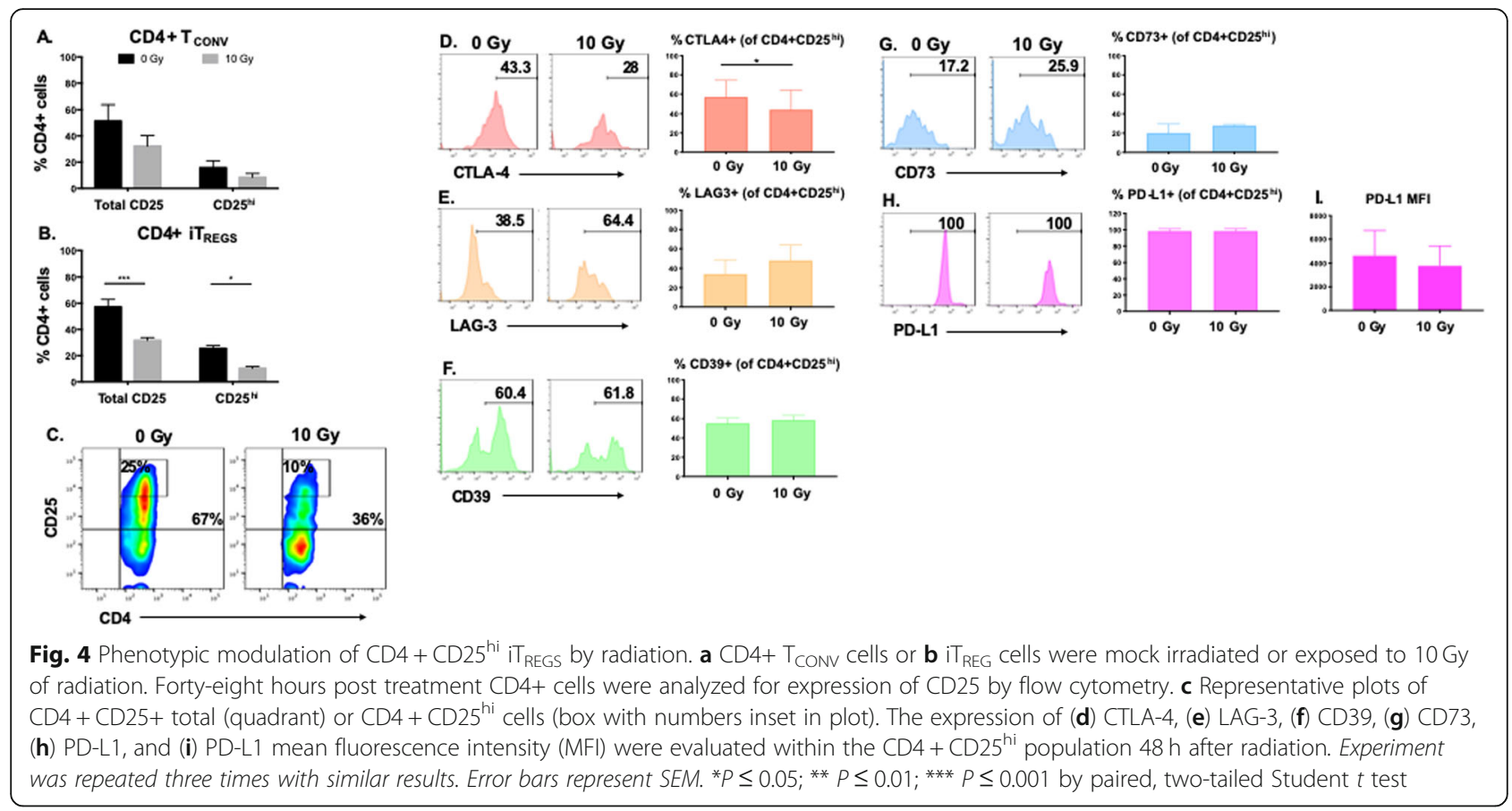

